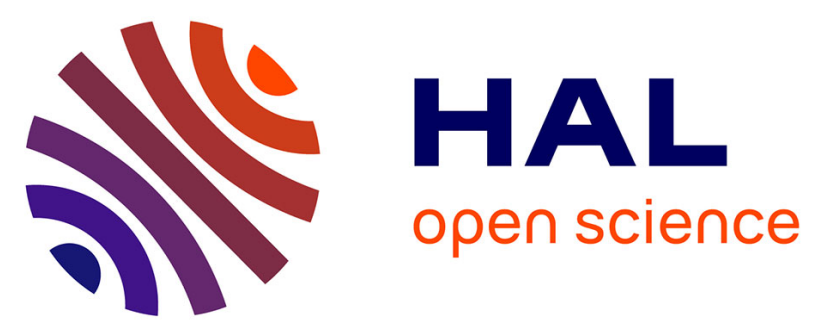

\title{
Two novel macrocyclic organotin (IV) carboxylates based on bipyrazoledicarboxylic acid derivatives: Syntheses, crystal structures and antifungal activities
}

Mohammed Dahmani, Tarik Harit, Abdelkader Et-Touhami, Abderrahmane Yahyi, Driss Eddike, Monique Tillard, Redouane Benabbes

\section{To cite this version:}

Mohammed Dahmani, Tarik Harit, Abdelkader Et-Touhami, Abderrahmane Yahyi, Driss Eddike, et al.. Two novel macrocyclic organotin (IV) carboxylates based on bipyrazoledicarboxylic acid derivatives: Syntheses, crystal structures and antifungal activities. Journal of Organometallic Chemistry, 2021, 948, pp.121913. 10.1016/j.jorganchem.2021.121913 . hal-03288001

\section{HAL Id: hal-03288001 \\ https://hal.umontpellier.fr/hal-03288001}

Submitted on 29 Sep 2021

HAL is a multi-disciplinary open access archive for the deposit and dissemination of scientific research documents, whether they are published or not. The documents may come from teaching and research institutions in France or abroad, or from public or private research centers.
L'archive ouverte pluridisciplinaire HAL, est destinée au dépôt et à la diffusion de documents scientifiques de niveau recherche, publiés ou non, émanant des établissements d'enseignement et de recherche français ou étrangers, des laboratoires publics ou privés. 


\title{
Two novel macrocyclic organotin (IV) carboxylates based on bipyrazoledicarboxylic acid derivatives: syntheses, crystal structures and antifungal activities.
}

\author{
Mohammed Dahmani ${ }^{\mathrm{a}}$, Tarik Harit ${ }^{\mathrm{a}}$, Abdelkader Et-touhami ${ }^{\mathrm{a},{ }^{*}}$, Abderrahmane Yahyi $^{\mathrm{a}}$, \\ Driss Eddike ${ }^{\mathrm{b}}$, Monique Tillard ${ }^{\mathrm{c}}$, Redouane Benabbes ${ }^{\mathrm{d}}$. \\ ${ }^{a}$ Laboratory of Applied Chemistry and Environment-ECOMP, Faculty of Sciences, \\ Mohammed First University Bd Mohamed VI, BP: 717, Oujda 60000, Morocco. \\ ${ }^{b}$ Laboratory of Applied Chemistry and Environment-CSM, Faculty of Sciences, \\ Mohamed First University, Bd Mohamed VI, BP 717, Oujda 60000, Morocco. \\ ${ }^{c} I C G M$, CNRS, Univ Montpellier, ENSCM, Montpellier, France. \\ ${ }^{d}$ Laboratory of Biochemistry, Faculty of Sciences, Mohammed First University, 60000 \\ Oujda, Morocco.
}

Corresponding author: Abdelkader Et-touhami

Tel: (+212) 667126373; Fax :( +212) 536500603; E-mail: touhami_52@yahoo.fr 


\begin{abstract}
Two new organotin (IV) bipyrazole-dicarboxylate macrocyclic complexes, C1 $\left(\mathrm{C}_{58} \mathrm{H}_{100} \mathrm{~N}_{8} \mathrm{O}_{10} \mathrm{Sn}_{4}\right)$ and $\mathrm{C} 2\left(\mathrm{C}_{58} \mathrm{H}_{100} \mathrm{~N}_{8} \mathrm{O}_{12} \mathrm{Sn}_{4}, 4 \mathrm{H}_{2} \mathrm{O}\right)$, are synthesized by reaction of the bipyrazole-dicarboxylic acids $\quad \mathbf{L 1}=\quad$ 1,1'-(propane-1,3-diyl)bis(5-methyl-1H-pyrazole-3carboxylic acid) and $\mathbf{L} 2=1,1$ '-(2-hydroxypropane-1,3-diyl)bis(5-methyl-1H-pyrazole-3carboxylic acid) with oxide di-(n-butyl)tin. The structure of these complexes is characterized using NMR, IR and UV-visible spectroscopies as well as single crystal X-ray diffraction. Compound $\mathbf{C 1}$ crystallizes within the triclinic symmetry in space group $\mathrm{P} \overline{\mathbf{1}}$ with $\mathrm{a}=$ 12.9410(5), $b=13.6143(5), c=22.7675(8) \AA, \alpha=92.981(1), \beta=91.180(1), \gamma=116.966(1)^{\circ}$, while C2 crystallizes within the rhombohedral symmetry in space group R3 with $a=b=29.4419(5)$, $\mathrm{c}=23.0326(5) \AA, \alpha=\beta=90$ and $\gamma=120^{\circ}$. The analysis by X-ray crystallography diffraction reveals that both complexes are centrosymmetric macrocycles and contain a tetra-nuclear four-fold ladder-like organo-oxotin cluster. Two Sn atoms are found to be five-coordinated while the two others are four-coordinated. The antifungal activity of these metal-cyclic compounds $\mathbf{C 1}$ and $\mathbf{C 2}$ is examined and compared to that of the corresponding ligands against the pathogenic strain Fusarium oxysporum f. sp. albedinis. The complexes $\mathbf{C 1}$ and $\mathbf{C 2}$ possess an interesting fungicidal power even higher than the ligands $\mathbf{L 1}$ and $\mathbf{L 2}$.
\end{abstract}

Keywords: Organotin (IV) compound; Synthesis; Bipyrazole-dicarboxylic Acid; Crystal Structure; Antifungal Activity; Macrocycle. 


\section{Introduction}

Organotin (IV) carboxylate complexes have generated a lot of interest among the scientific community over the past 20 years. ${ }^{1-6}$ This is due to their structural diversity and their potential application in several fields, ${ }^{7-9}$ especially in medicinal chemistry. ${ }^{8,9}$ In fact, the literature reports that organotin carboxylates can act as antitumor, ${ }^{8}, 9$ antiviral, ${ }^{10,} 11$ antifungal, ${ }^{12,13}$ antibacterial, ${ }^{14,}{ }^{15}$ anti-proliferative, ${ }^{16,}{ }^{17}$ anti-inflammatory, ${ }^{18}$ and antioxidant potent agents. $^{19,20}$

Among the studies reporting on the various types of organotin complexes, only a few describe the synthesis and characterization of macrocyclic organotin compounds. Chandrasekhar et al. present macrocycle-containing coordination polymers elaborated by condensing the 3,5-pyrazole dicarboxylic acid with di- and tri-organotin substrates. ${ }^{21}$ They also communicate on the synthesis of one- and two-dimensional coordination polymers that contain organotin macrocycles by condensation of $\left(n-\mathrm{Bu}_{3} \mathrm{Sn}\right)_{2} \mathrm{O}$ with several pyridine dicarboxylic acids. ${ }^{22}$ In 2011, Du and coworkers have reported the synthesis of six new organotin carboxylates based on derivatives of the 1,3-benzenedicarboxylic and 1,4benzenedicarboxylic acids. ${ }^{23}$ One of these compounds is shown to be a more efficient antitumor agent against HeLa than the cis-platinum used clinically. Moreover, Sougoule et al. describe the synthesis and characterization of a novel macrocyclic organotin carboxylate prepared by reaction of di-(n-butyl)tin oxide with the 3-(carboxy-methoxy-phenoxy) acetic acid. ${ }^{24}$ Their study has also shown a good antitumor activity for this complex against HeLa cells. The elaboration of an organotin(IV) macrocycle based on (1,3,4-thiadiazole-2,5diyldithio) diacetic acid is also published by Yan et al. who have evaluated its antitumor activity against A549, HeLa and HepG-2 cells. ${ }^{25}$ Recently, Rojas-León et al. reported the synthesis and the characterization of a family of tin-based compounds, 21- and 22-membered 
macrocycles, which contain 2,5-pyridine dicarboxylate, 3,5-pyridine dicarboxylate and piperazine moieties. $^{26}$

On the other hand, bipyrazolic compounds bearing two carboxylic groups (Fig. 1) are of increased interest due to their abilities to form stable complexes with heavy metals, such as copper and cobalt. ${ }^{27-29}$

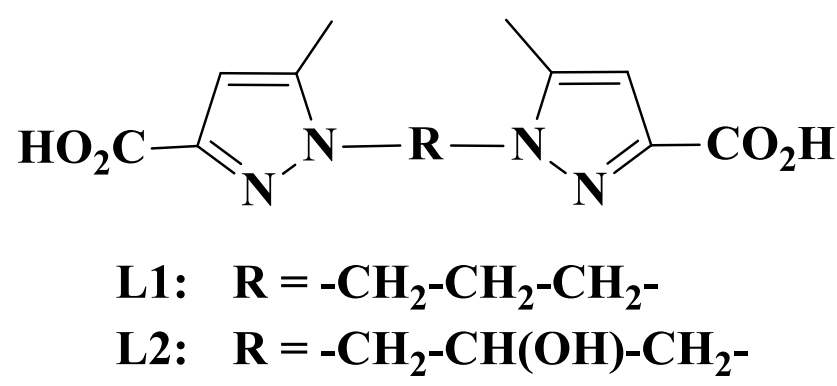

Fig. 1 Examples of bipyrazolic dicarboxylic acids

However, and to the best of our knowledge, no study reports the synthesis of organotin macrocyclic compounds based on bipyrazole functionalized by dicarboxylic groups.

Thus, this paper presents a pioneering work with the synthesis and characterization of two organotin macrocycles based on such bipyrazolic ligands (Fig. 1), which differ by the nature of the spacers between pyrazolic rings. The subsequent modifications in the crystal structures of the two complexes are discussed. The antifungal activity of these complexes is also examined against the pathogenic fungus Fusarium oxysporum $f$. sp. albedinis compared to their corresponding ligands.

\section{Experimental}

\subsection{General and instrumental}

All reagents and solvents were purchased from Sigma-Aldrich and used as received. A spectrometer BRÜKER AC 300 was used to record the NMR spectra. Spin resonances are given in the form of chemical shifts $(\delta)$ in parts per million (ppm) with reference to the 
residual peak of the solvent used as an internal standard, namely $\mathrm{CDCl}_{3} 7.27 \mathrm{ppm}$ and DMSO-d ${ }_{6} 2.50$ ppm for ${ }^{1} \mathrm{H}$ NMR, and $77 \mathrm{ppm} 39.5$ ppm for ${ }^{13} \mathrm{C}$ NMR. Spin multiplicity is presented by $\mathrm{s}=$ singlet, $\mathrm{d}=$ doublet, $\mathrm{t}=$ triplet, $\mathrm{q}=$ quartet, $\mathrm{m}=$ multiplet. The melting point (uncorrected) was recorded in a capillary using IA9100 (Electrothermal) apparatus. Elemental analysis was carried out on EA 3000 analyzer. The FTIR spectra were acquired on a Shimadzu FTIR 8400s spectrophotometer and the UV-Vis spectra on a Shimadzu Europe UV-1650PC equipment.

\subsection{Synthesis}

\subsubsection{Synthesis of ligands $\mathbf{L} \mathbf{1}$ and $\mathbf{L} 2$}

The two ligands 1,1'-(propane-1,3-diyl)bis(5-methyl-1H-pyrazole-3-carboxylic acid) L1 and 1,1'-(2-hydroxypropane-1,3-diyl)bis(5-methyl-1H-pyrazole-3-carboxylic acid) L2 were synthesized following the procedure already described in our previous works. ${ }^{27,29}$

\subsubsection{Synthesis of organotin (IV) carboxylates $\boldsymbol{C 1}$ and $\boldsymbol{C 2}$}

The details of the synthetic experiments to complexes $\mathbf{C 1}$ and $\mathbf{C 2}$ are displayed in Scheme 1 . 


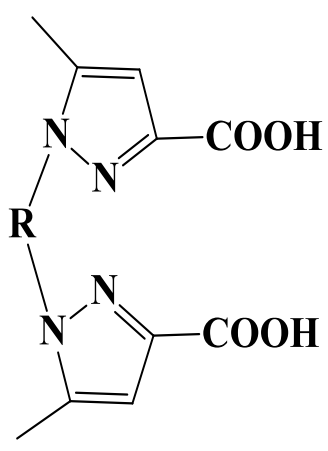

L1, L2

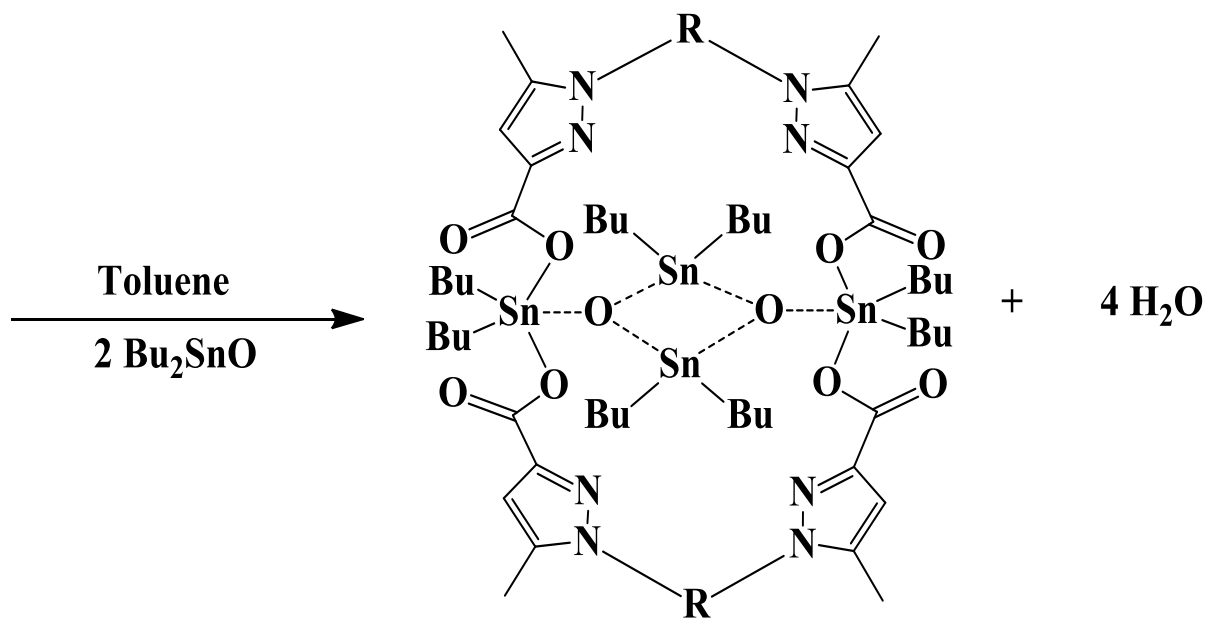

$\mathrm{C} 1, \mathrm{C} 2$

$\mathrm{L1} ; \mathrm{C1}: \quad \mathrm{R}=-\mathrm{CH}_{2}-\mathrm{CH}_{2}-\mathrm{CH}_{2}-$

L2; $\mathrm{C} 2: \quad \mathrm{R}=-\mathrm{CH}_{2}-\mathrm{CH}(\mathrm{OH})-\mathrm{CH}_{2}-$

Scheme 1. Synthesis pathway of tin complexes C1-C2.

\subsubsection{Synthesis of macrocyclic complex $\boldsymbol{C 1}$}

A mixture of di-n-butyltin oxide $(1 \mathrm{mmol})$ and $\mathbf{~ L 1}(0.5 \mathrm{mmol})$ was heated under reflux in toluene $(50 \mathrm{~mL})$ for $10 \mathrm{~h}$ in a Dean-Stark apparatus for azeotropic removal of the water formed in the reaction. After cooling to room temperature, the solution was filtered. Suitable colorless crystals were obtained by slow evaporation of the solvent. Yield $=67 \% . \underline{\mathrm{mp}}=104-105{ }^{\circ} \mathrm{C} . \underline{\mathrm{H}}$ NMR $\left(300 \mathrm{MHz}, \mathrm{DMSO}_{-} \mathrm{d}_{6}\right) \delta: 0.62-0.81\left(\mathrm{t}, 24 \mathrm{H}, J=8 \mathrm{~Hz}, \mathrm{CH}_{3}\right) ; 1.29-1.60(\mathrm{~m}, 48 \mathrm{H}$, $\left.\mathrm{CH}_{2} \underline{\mathrm{CH}}_{2} \underline{\mathrm{CH}}_{2}\right) ; 2.25\left(\mathrm{~s}, 12 \mathrm{H}, \mathrm{CH}_{3}-\mathrm{Pz}\right) ; 2.41\left(\mathrm{~m}, 4 \mathrm{H},-\mathrm{C}_{2}-\mathrm{CH}_{2}-\mathrm{N}\right) ; 4.10$ (t, 8H, J=6 Hz,$\left.\mathrm{C}_{2}-\mathrm{N}\right) ; 6.53(\mathrm{~s}, 4 \mathrm{H}, \mathrm{HPz}) .{ }^{13} \mathrm{C} \mathrm{NMR}\left(75 \mathrm{MHz}, \mathrm{DMSO}-\mathrm{d}_{6}\right) \delta: 11.27\left(\mathrm{CH}_{3}-\mathrm{Pz}\right) ; 14.03\left(\mathrm{CH}_{2}-\right.$ $\left.\underline{\mathrm{CH}}_{3}\right) ; 26.06\left(\underline{\mathrm{CH}}_{2}-\mathrm{CH}_{2}-\mathrm{N}\right) ; 26.91,27.07,27.47,28.3,28.44\left(\mathrm{CH}_{2}-\mathrm{CH}_{2}-\mathrm{CH}_{2}\right) ; 46.43\left(-\underline{\mathrm{CH}}_{2}-\right.$ $\mathrm{N}) ; 108.42(\mathrm{CH}-\mathrm{Pz}) ; 138.85\left(\mathrm{CH}_{3}-\mathrm{C}=\mathrm{C}\right) ; 145.30(\mathrm{C}-\mathrm{C}=\mathrm{O}) ; 166.28(\mathrm{C}=\mathrm{O}) . \underline{\mathrm{IR}\left(\mathrm{cm}^{-1}\right)}$ : 1630 $v_{\mathrm{as}}(\mathrm{COO}) ; 1420 v_{\mathrm{s}}(\mathrm{COO}) ; 560 v(\mathrm{Sn}-\mathrm{C}) ; 465 v(\mathrm{Sn}-\mathrm{O})$. Anal. Calcd for $\mathrm{C}_{58} \mathrm{H}_{100} \mathrm{~N}_{8} \mathrm{O}_{10} \mathrm{Sn}_{4}: \mathrm{C}$, 45.11; H, 6.53; N, 7.26; O, 10.36; Found: C, 45.14; H, 6.56; N, 7.29; O, 10.38. 


\subsubsection{Synthesis of macrocyclic complex $\boldsymbol{C 2}$}

The complex $\mathbf{C 2}$ was synthesized in a similar way to $\mathbf{C 1}$. Suitable colorless crystals were obtained by slow evaporation of the solvent. $\underline{\text { Yield }}=62 \% . \underline{\mathrm{mp}}=97-98{ }^{\circ} \mathrm{C} .{ }^{1} \mathrm{H}$ NMR $(250$ MHz, DMSO-d $\left.\mathrm{d}_{6}\right) \delta: 0.6-1.60\left(\mathrm{~m}, 72 \mathrm{H}, \mathrm{CH}_{2} \mathrm{CH}_{2} \mathrm{CH}_{2} \mathrm{CH}_{3}\right) ; 1.75\left(\mathrm{~s}, 8 \mathrm{H}, \mathrm{H}_{2} \mathrm{O}\right) ; 2.27(\mathrm{~s}, 12 \mathrm{H}$, $\left.\mathrm{CH}_{3} \mathrm{Pz}\right) ; 3.95-4.24$ (m, 8H, $\left.\underline{\mathrm{CH}}_{2}-\mathrm{CH}(\mathrm{HO})-\underline{\mathrm{C}}_{2}\right) ; 4.73$ (m, 2H, HO-Cㅌ- $\left.\mathrm{CH}_{2}-\mathrm{Pz}\right) ; 5.57$ (d, 2H, $\left.J=6 \mathrm{~Hz}, \underline{\mathrm{HO}}-\mathrm{CH}-\mathrm{CH}_{2}\right) ; \quad 6.45(\mathrm{~s}, 4 \mathrm{H}, \quad \mathrm{HPz}) .{ }^{13} \mathrm{C} \mathrm{NMR}\left(75 \mathrm{MHz}, \mathrm{DMSO}-\mathrm{d}_{6}\right) \delta: 11.37$ $\left(\mathrm{CH}_{3} \mathrm{Pz}\right) ; 13.62,13.64\left(\mathrm{CH}_{2}-\underline{\mathrm{CH}}_{3}\right) ; 25.85,26.74,26.95,27.45\left(\mathrm{CH}_{2}-\mathrm{CH}_{2}-\mathrm{CH}_{2}\right) ; 52.45\left(\underline{\mathrm{CH}}_{2}-\right.$ $\left.\mathrm{CH}(\mathrm{HO})-\underline{\mathrm{CH}}_{2}\right) ; 56.48\left(\mathrm{CH}_{2}-\underline{\mathrm{CH}}(\mathrm{HO})-\mathrm{CH}_{2}\right) ; 108.42(\underline{\mathrm{CH}}-\mathrm{Pz}) ; 141.63\left(\mathrm{CH}_{3}-\underline{\mathrm{C}}=\mathrm{C}\right) ; 144.55(\underline{\mathrm{C}}-$ $\mathrm{C}=\mathrm{O}) ; 165.92(\mathrm{C}=\mathrm{O}) . \underline{\mathrm{IR}\left(\mathrm{cm}^{-1}\right)}: 1630 v_{\mathrm{as}}(\mathrm{COO}) ; 1420 v_{\mathrm{s}}(\mathrm{COO}) ; 560 v(\mathrm{Sn}-\mathrm{C}) ; 465 v(\mathrm{Sn}-\mathrm{O})$. Anal. Calcd for $\mathrm{C}_{58} \mathrm{H}_{100} \mathrm{~N}_{8} \mathrm{O}_{12} \mathrm{Sn}_{4} .4 \mathrm{H}_{2} \mathrm{O}: \mathrm{C}, 42.26 ; \mathrm{H}, 6.60 ; \mathrm{N}, 6.80 ; \mathrm{O}, 15.53$; Found: C, 42.29; $\mathrm{H}, 6.64 ; \mathrm{N}, 6.83 ; \mathrm{O}, 15.56$.

\subsection{X-ray crystallography}

Crystals suitable for X-ray data collection were selected using a stereo microscope with a polarizing filter. The diffracted intensities were recorded on a 4-circle diffractometer (Bruker D8 Venture) equipped with a Mo K $\alpha$ micro-source (Incoatec I $\mu \mathrm{S} 3.0,110 \mu \mathrm{m}$ beam, $\lambda=$ $0.71073 \AA$ A) and a Photon II CPAD detector. Data were handled with the Apex software suite for reduction, absorption corrections (multi-scan SADABS), ${ }^{30}$ and the structures were solved and refined using the SHELX programs. ${ }^{31,32}$ For the non- $\mathrm{H}$ atoms, all positional and anisotropic displacement parameters were refined while the $\mathrm{H}$-atoms were treated using a riding model with displacement parameters equal to $1.2\left(1.5\right.$ for $\left.-\mathrm{CH}_{3}\right)$ times the $\mathrm{U}_{\text {eq }}$ of the parent atom. The crystal data and the main refinement parameters are given in Table 1 . The full crystallographic data (CIF files) can be obtained free of charge from the Cambridge Crystallographic Data Center mentioning the corresponding CCDC numbers. ${ }^{33}$

Table 1. Crystal data and refinement parameters. 


\begin{tabular}{|c|c|c|}
\hline Compound & $\mathrm{C}_{58} \mathrm{H}_{100} \mathrm{~N}_{8} \mathrm{O}_{10} \mathrm{Sn}_{4}(\mathbf{C 1})$ & $\mathrm{C}_{58} \mathrm{H}_{100} \mathrm{~N}_{8} \mathrm{O}_{12} \mathrm{Sn}_{4}, 4 \mathrm{H}_{2} \mathrm{O}(\mathbf{C 2})$ \\
\hline CCDC number & 2070454 & 2070462 \\
\hline $\begin{array}{l}\text { System, space group } \\
\text { Unit cell dimensions } \AA, \circ \\
\text { Volume } \AA^{3}\end{array}$ & $\begin{array}{c}\text { Triclinic, } P \overline{1} \\
a=12.9410(5), b=13.6143(5), \\
c=22.7675(8), \alpha=92.981(1), \\
\beta=91.180(1), \gamma=116.966(1) \\
3565.9(2)\end{array}$ & $\begin{array}{c}\text { Rhombohedral, R3 } \\
\mathrm{a}=\mathrm{b}=29.4419(5), \mathrm{c}=23.0326(5) \\
\alpha=\beta=90, \gamma=120 \\
17290.4(7)\end{array}$ \\
\hline $\begin{array}{l}\text { Temperature } K \\
M, Z \\
\text { Calculated density } \\
M g / m^{3} \\
{\text { Abs. coefficient } \mathrm{mm}^{-1}} \\
\theta \text { range } \\
\text { Index ranges } \\
\text { Unique reflections. } \\
\text { Data / restraints / params. } \\
\text { Goodness-of-fit on } \mathrm{F}^{2} \\
\text { Flack parameter } \\
\text { Final R indices [I }>2 \sigma(\mathrm{I})] \\
\text { R indices (all data) } \\
\text { Extinction coefficient } \\
\text { Residual density } e . \AA^{-3}\end{array}$ & $\begin{array}{c}\mathbf{2 9 6}(\mathbf{2}) \\
\mathbf{1 5 4 3 . 2 1 , 2} \\
\mathbf{1 . 4 3 7} \\
\mathbf{1 . 4 3 9} \\
2.455 \text { to } 27.502 \\
-16 \leq h \leq 16,-17 \leq k \leq 17,-29 \leq l \leq 29 \\
16311\left[\mathrm{R}_{\text {int }}=0.0418\right] \\
16311 / 54 / 736 \\
1.045 \\
- \\
\mathrm{R} 1=0.0426, \mathrm{wR} 2=0.1191 \\
\mathrm{R} 1=0.0654, \mathrm{wR} 2=0.1396 \\
0.0070(7) \\
4.086 \text { and }-0.749\end{array}$ & $\begin{array}{c}\mathbf{1 7 3}(\mathbf{2}) \\
\mathbf{1 6 4 8 . 2 8 , 9} \\
\mathbf{1 . 4 2 2} \\
\mathbf{1 . 3 4 6} \\
1.940 \text { to } 27.993 \\
-38 \leq h \leq 38,-38 \leq k \leq 33,-30 \leq l \leq 30 \\
18571\left[\mathrm{R}_{\text {int }}=0.0418\right] \\
18571 / 19 / 817 \\
1.096 \\
0.44(3) \\
\mathrm{R} 1=0.0310, \mathrm{wR} 2=0.0780 \\
\mathrm{R} 1=0.0450, \mathrm{wR} 2=0.0890 \\
0.0089(9) \\
1.352 \text { and }-0.810\end{array}$ \\
\hline
\end{tabular}

The colorless and diamond-shaped crystals of $\mathbf{C 1}$, obtained by recrystallization from a mixture of solvents (ethanol/diethyl-ether), were cut into small parts and two fragments were used for data collection at room temperature. Subsequent low-temperature recording failed, giving only a data overlay of multiple components, even for crystals grown from ethanol/dichloromethane solvents. It appears that lowering the temperature causes a misalignment of components generated by cleavage during the crystal cutting operation. Despite this drawback, the structure could be solved in the $\mathrm{P} \overline{1}$ centrosymmetric space group (according to statistics) from the data collected at ambient temperature. The refinement of the main part of the molecule converged to $\mathrm{R} 1 \sim 10 \%$, then the $\mathrm{C}$ atoms of the butyl groups attached to tin atoms were found in the Fourier difference. Most aliphatic branches refine normally, except three which have stability issues that could not be resolved in the noncentrosymmetric space group P1. Then geometrical DFIX restraints were applied to the $\mathrm{C}-\mathrm{C}$ 
bonds of all the butyl groups. The presence of large ellipsoids would require consideration of disorder to further improve the refinement, but this was not possible with the current data sets.

The data collection was performed both at room temperature and $173 \mathrm{~K}$ for fragments of the colorless crystals of $\mathbf{C 2}$. Statistics indicate centrosymmetry and data appear to be rhombohedral with a surprisingly high symmetry compared to $\mathbf{C} 1$. The unit cell was defined with the hexagonal axes $(a=b=29.44, c=23.03 \AA, \alpha=\beta=90, \gamma=120)$ as conventionally done for rhombohedral systems, preferred to the rhombohedral axes of the reduced cell $\left(\mathbf{a}=\mathbf{b}=\mathbf{c}=18.7 \AA, \alpha=\beta=\gamma=104^{\circ}\right)$. The structure was initially solved in the centrosymmetric space group $\mathrm{R} \overline{\mathrm{3}}$ but some abnormal/strange behavior was noted at the butyl chain atoms in the refinements even when using the low-temperature data set. Attempts to model and to solve such intricate disorder remained unsuccessful. This situation resembles that of an example of twinning reported by Sheldrick ${ }^{34}$ but, although a (pseudo)merohedral twin can be suspected, no twin law could be found and none of the attempts considering alternative lattices and/or space groups was fully satisfactory. In fact, the 3-fold symmetry could be generated by several crystal components having potentially lower symmetry, as is the case for the monoclinic crystals in this example ${ }^{34}$ appearing to be rhombohedral from the diffraction symmetry. Hence, the structure which is given here in the non-centrosymmetric space group R3 may not be described with its "true" symmetry/cell. Structural validation is to be provided with the study of better crystallized and higher quality crystals in future works. Four water molecules can be located around the cell origin from the Fourier difference, their $\mathrm{H}$-atoms are involved in $\mathrm{H}$ bonds and refined using DFIX instructions. Likewise in the nearby butyl chains, restraints were applied to the $\mathrm{C}-\mathrm{C}$ distances involving atoms with fairly large ellipsoids. In addition to this phenomenon related to the great mobility of the alkyl chains, small residual density peaks distributed along the $c$-axis indicate that the accessible void remaining around the 
origin ( $3 a$ positions) could be filled with additional water molecules. Such molecules would be in more disordered positions due to their lack of involvement in H-bonds. Or else, the molecular arrangement induced by the solvent molecules present in these channels could remain strongly stabilized by the hydrogen bonds even after total or partial elimination of the solvent (disordered residual solvent molecules).

\subsection{Antifungal activity}

The in vitro antifungal activity of the di-n-butylyltin (IV) dicarboxylate complexes (C1, C2) and their corresponding ligands (L1, L2) was examined against fungus Fusarium oxysporum f. sp. albedinis (FAO) using the agar diffusion technique, as reported in our recent work. ${ }^{13}$ Potato dextrose agar (PDA) medium was mixed with different volumes $(40,160$, and $500 \mu \mathrm{L})$ of DMSO solutions of the complexes and the corresponding ligands. Then, discs (6 $\mathrm{mm}$ in diameter) of the microorganism (FAO) were put in the middle of these Petri plates. After incubation at $28{ }^{\circ} \mathrm{C}$ for 7 days, inhibition percentages (\% I) of the growth rate were calculated as follows: \% $\mathbf{I}=((\mathbf{D o}-\mathbf{D x}) / \mathbf{D o}) \times \mathbf{1 0 0}$, where Do and Dx are the respective diameters $(\mathrm{cm})$ of the FOA in the absence and presence of the product tested. Benomyl was used as the positive control.

\section{Discussion}

\subsection{NMR spectroscopy}

In the ${ }^{1} \mathrm{H}$ NMR spectra of the macrocyclic organotin carboxylates $\mathbf{C 1}$ and $\mathbf{C 2}$, we note the absence of signal associated with the carboxyl proton that appears around $12.5 \mathrm{ppm}$ for the ligands $\mathbf{L} \mathbf{1}$ and $\mathbf{L 2} .^{27,29}$ This evidences the participation of both carboxylic groups in the coordination of the tin atom in these complexes. On the other hand, the rest of the protons belonging to the ligands keep the same integration and multiplicities as in the free ligands. The protons of the butyl groups attached to the Sn atom are found at chemical shifts from 0.6 
to $1.8 \mathrm{ppm}$, in a range where some signals are duplicated twice (Fig. 2). Furthermore, the NMR spectrum of the complex $\mathbf{C 2}$ displays a massive pic at $1.65 \mathrm{ppm}$, a signal which is attributed to the protons of the four water molecules resulting from the reaction.

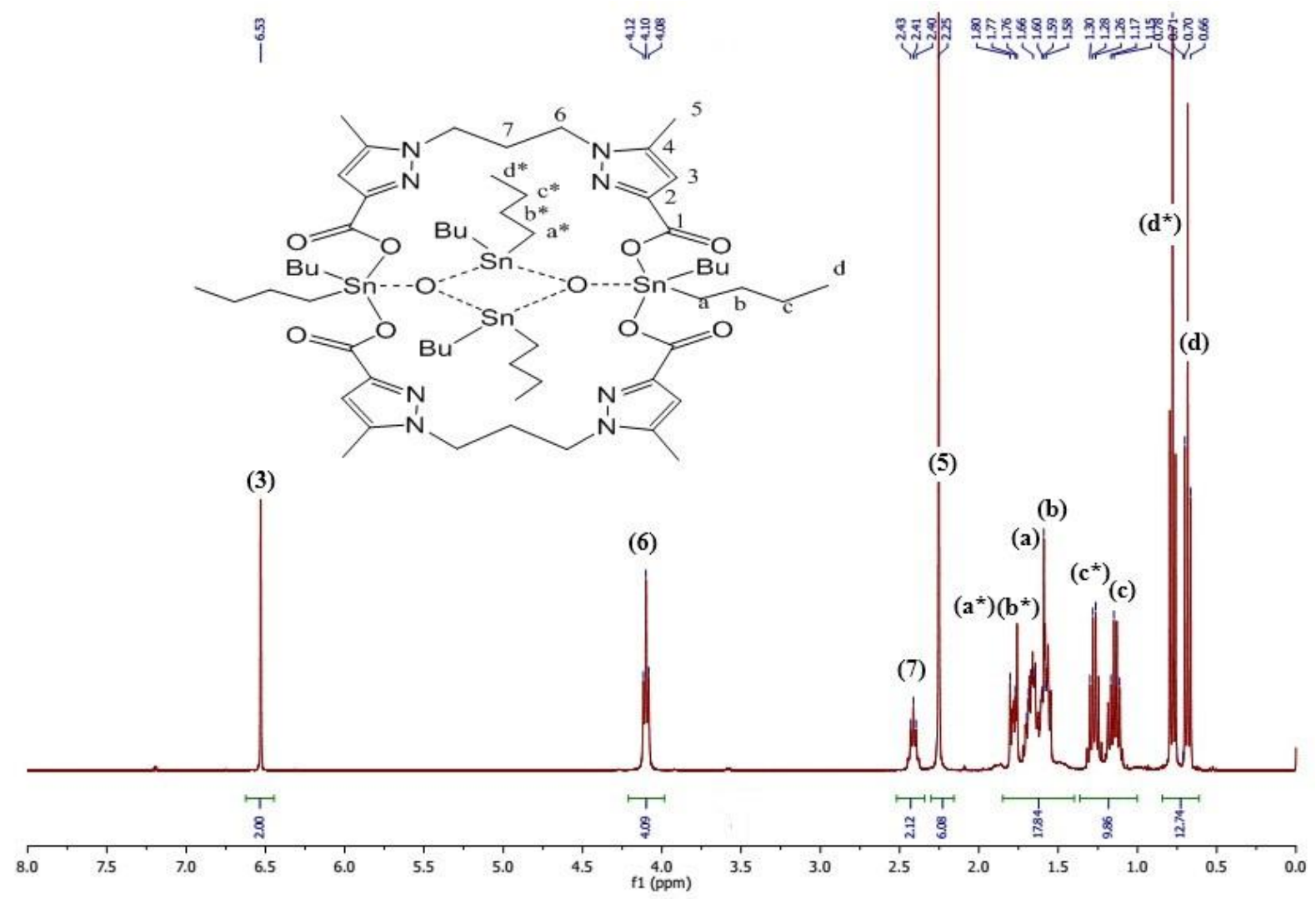

Fig. 2. ${ }^{1} \mathrm{H}$ NMR spectrum of $\mathbf{C 1}$. 


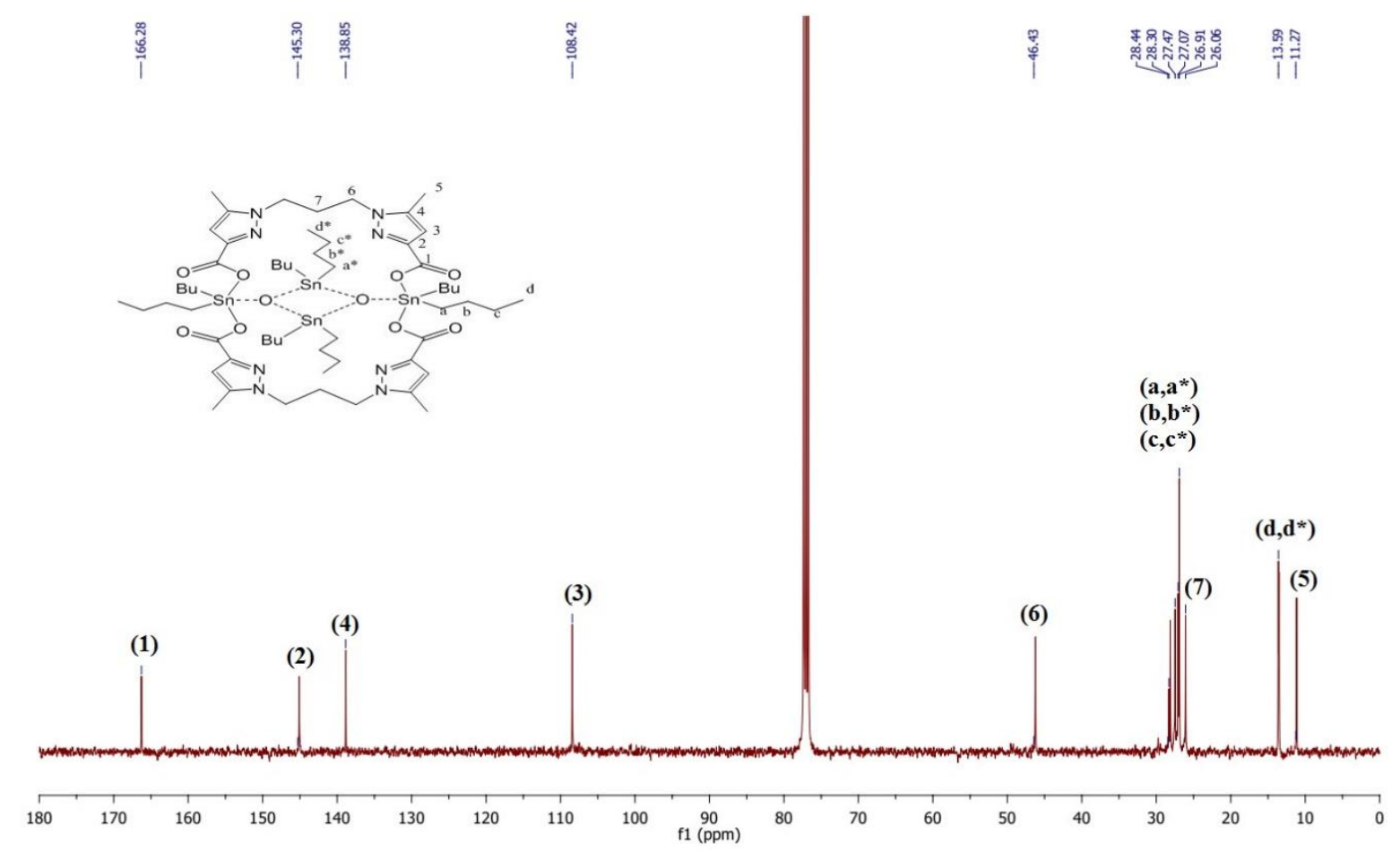

Fig. 3. ${ }^{13} \mathrm{C}$ NMR spectrum of $\mathbf{C} 1$.

This proves the presence of two butyl categories and the result agrees with the crystal structures determined for the complexes $\mathbf{C 1}$ and C2. As well, the above remark is also confirmed by the ${ }^{13} \mathrm{C}$ NMR spectra (Fig. 3.) of both complexes in which is observed the duplication of some carbon atom signals of the butyl group. Also, the signals corresponding to the carboxyl carbon atoms of the complexes $\mathbf{C 1}$ and $\mathbf{C 2}$, appearing at 166 and $167 \mathrm{ppm}$ respectively, show a slight downfield shift compared to their free ligands $\mathbf{L 1}$ and $\mathbf{L 2}$. These results are very consistent with those reported in several related works and such behavior is due to a transfer of the electron density from the ligands towards the tin atoms. ${ }^{35}$

\subsection{FTIR and UV-visible spectroscopy}

In the FTIR spectra of the complexes $\mathbf{C} 1$ (Fig. 4) and $\mathbf{C 2}$, no large band in the range of $3500-2850 \mathrm{~cm}^{-1}$ is observed attributed to $\mathrm{O}-\mathrm{H}$ stretching vibrations as in free ligands. This indicates that the Sn-to-ligand bond is established via these sites. 


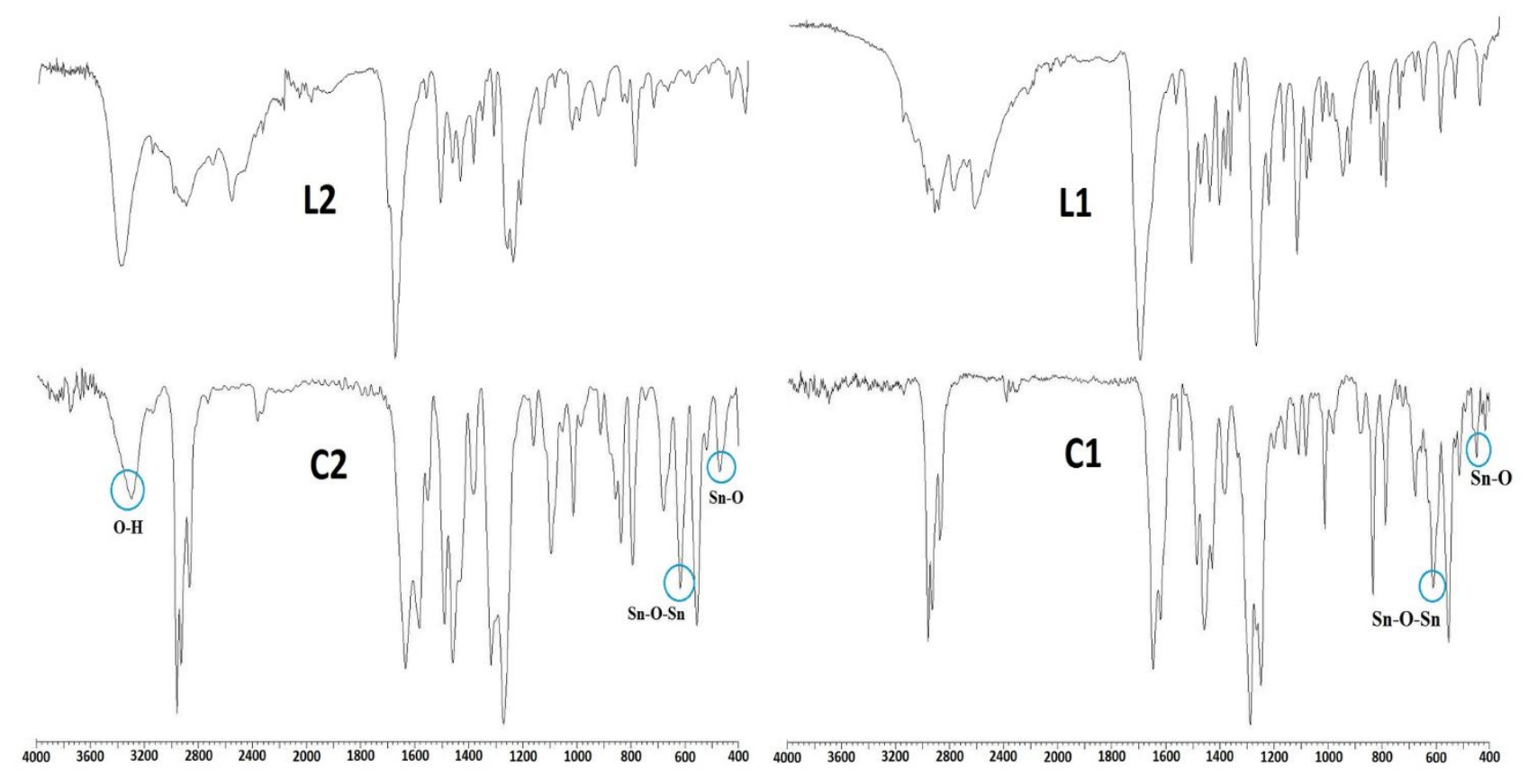

Fig. 4. FTIR spectra of $\mathbf{L} 1$ ligand and their corresponding complexes $\mathbf{C 1}$.

In addition, strong absorption peaks are observed at $\sim 1670$ and $1463 \mathrm{~cm}^{-1}$, they are attributed to the asymmetric and symmetric vibrations of the COO fragments (Fig. 3). The difference between the asymmetric and symmetric COO stretching vibrations, $\Delta v=v_{\mathrm{as}}(\mathrm{OCO})$ $-v_{\mathrm{s}}(\mathrm{OCO})$ is known as a good tool to determine the mode of coordination of the ligands carboxylate with metals. ${ }^{23}$ The $\Delta v$ values higher than $200 \mathrm{~cm}^{-1}$ are typical for monodentate complexes. In the present case, the values of 210 and $215 \mathrm{~cm}^{-1}$ for $\mathbf{C 1}$ and $\mathbf{C 2}$, respectively, prove the monodentate coordination mode for both the carboxylic ligands $\mathbf{L 1}$ and $\mathbf{L 2}{ }^{13}$ On the other hand, the FTIR spectra of the two complexes $\mathbf{C 1}$ and $\mathbf{C 2}$ present bands at 640 and $631 \mathrm{~cm}^{-1}$. These bands are attributed to $v(\mathrm{Sn}-\mathrm{O}-\mathrm{Sn})$ stretching vibrations, which evidences the presence of diorganotin dicarboxylates containing $\mathrm{Sn}_{2} \mathrm{O}_{2}$ units. ${ }^{13,35}$ The conclusions drawn from the FTIR spectroscopy analysis are also in agreement with the structures obtained from X-ray crystallography.

The electronic absorption spectra have also been recorded for the two complexes in methylene chloride using UV-visible spectroscopy. The acquired spectra (Fig. 5) are found 
almost similar and show absorption peaks in the region $235-280 \mathrm{~nm}$ resulting from the $\pi-\pi *$ and the $\mathrm{n} \rightarrow \pi^{*}$ transitions. ${ }^{36}$
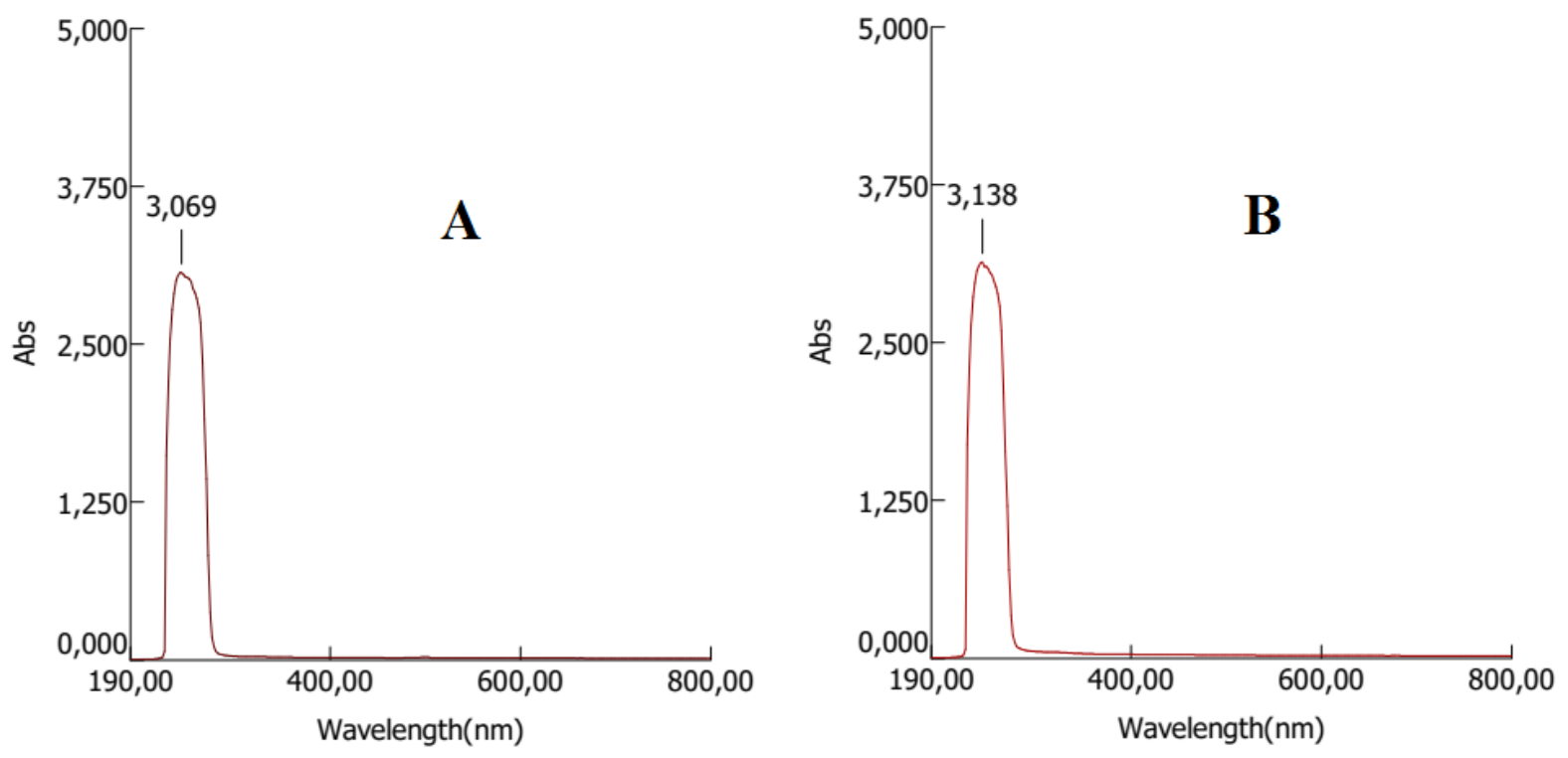

Fig. 5. UV-visible spectra of C1 (A) and C2 (B).

\subsection{Crystal structures of $\mathrm{C} 1$ and $\mathrm{C} 2$}

The triclinic P $\overline{1}$ unit cell of $\mathbf{C 1}$ contains two independent molecules $\mathrm{Sn}_{4} \mathrm{~N}_{8} \mathrm{O}_{10} \mathrm{C}_{58} \mathrm{H}_{100}$ otherwise formulated $\mathrm{Sn}_{4} \mathrm{~N}_{8} \mathrm{O}_{10} \mathrm{C}_{26} \mathrm{H}_{28} \mathrm{R}_{8}\left(\mathrm{R}=\mathrm{C}_{4} \mathrm{H}_{9}\right)$ since each $\mathrm{Sn}$ atom bears two butyl groups. Only one independent molecule of the formula $\mathrm{Sn}_{4} \mathrm{~N}_{8} \mathrm{O}_{12} \mathrm{C}_{58} \mathrm{H}_{100}$ (or $\mathrm{Sn}_{4} \mathrm{~N}_{8} \mathrm{O}_{12} \mathrm{C}_{26} \mathrm{H}_{28} \mathrm{R}_{8}$ ) is found in the noncentrosymmetric $\mathrm{R} 3$ rhombohedral cell of $\mathbf{C 2}$. As shown in the ORTEP ${ }^{37}$ drawing given in Fig. 6, the butyl chains are placed above and below the midplane of the molecules, both represented with their nearly planar $\mathrm{Sn}_{4} \mathrm{O}_{6}$ central cores approximately in the horizontal plane. The $\mathbf{C 2}$ molecule differs from the $\mathbf{C 1}$ molecule by the - $\mathrm{OH}$ group attached to the chain connecting the two pyrazole rings. Moreover, it crystallizes with water molecules to which it interacts through hydrogen bonds, as shown in Fig. 6. This could be the reason behind such a difference in the crystal symmetry between the two structures. 

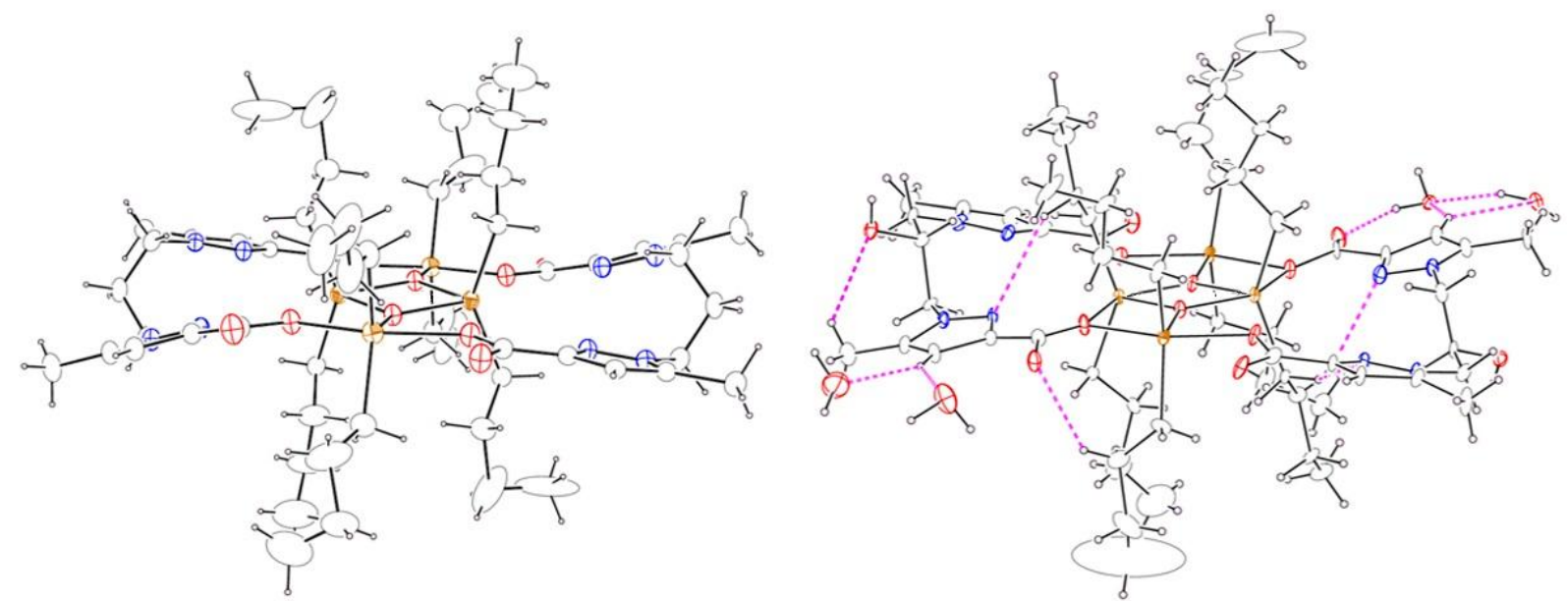

Fig. 6. The molecules $\mathrm{Sn}_{4} \mathrm{~N}_{8} \mathrm{O}_{10} \mathrm{C}_{26} \mathrm{H}_{28} \mathrm{R}_{8}$ (C1, left) and $\mathrm{Sn}_{4} \mathrm{~N}_{8} \mathrm{O}_{12} \mathrm{C}_{26} \mathrm{H}_{28} \mathrm{R}_{8}$ (C2, right) $(\mathrm{R}=$ $\mathrm{C}_{4} \mathrm{H}_{9}$ ). The H-bonds involving a $\mathbf{C 2}$ molecule and four water molecules are drawn as dashed lines and the ellipsoids are represented at $15 \%$ probability.

In the triclinic unit cell of $\mathbf{C 1}$, the two independent molecules are placed at the special positions $1 a\left(\begin{array}{lll}0 & 0 & 0\end{array}\right)$ and $1 h\left(1 / 21 / 2 \frac{1}{2}\right)$ on inversion centers and therefore are centrosymmetric. Instead, the molecule of $\mathbf{C 2}$ does not display an inversion center. Looking at the molecular representations given in Fig. 7, one first notices two types of Sn atoms, either coordinated with 2 or 3 oxygen neighbors. The existence of two coordination modes for the tin atoms was later confirmed by spectroscopic and RMN studies. Also, the molecules differ in geometry, especially at their $\mathrm{Sn}_{4} \mathrm{O}_{6}$ central cores. The first molecule of $\mathbf{C 1}$ displays a fairly regular oxygen arrangement around the Sn11 and Sn12 centers while the environment is much more distorted around the Sn21 and Sn22 centers within the second molecule of $\mathbf{C 1}$. The rest of the molecule therefore also differs. Such variations arise from molecular packing effects in the crystal and intermolecular interactions in the solid-state. 

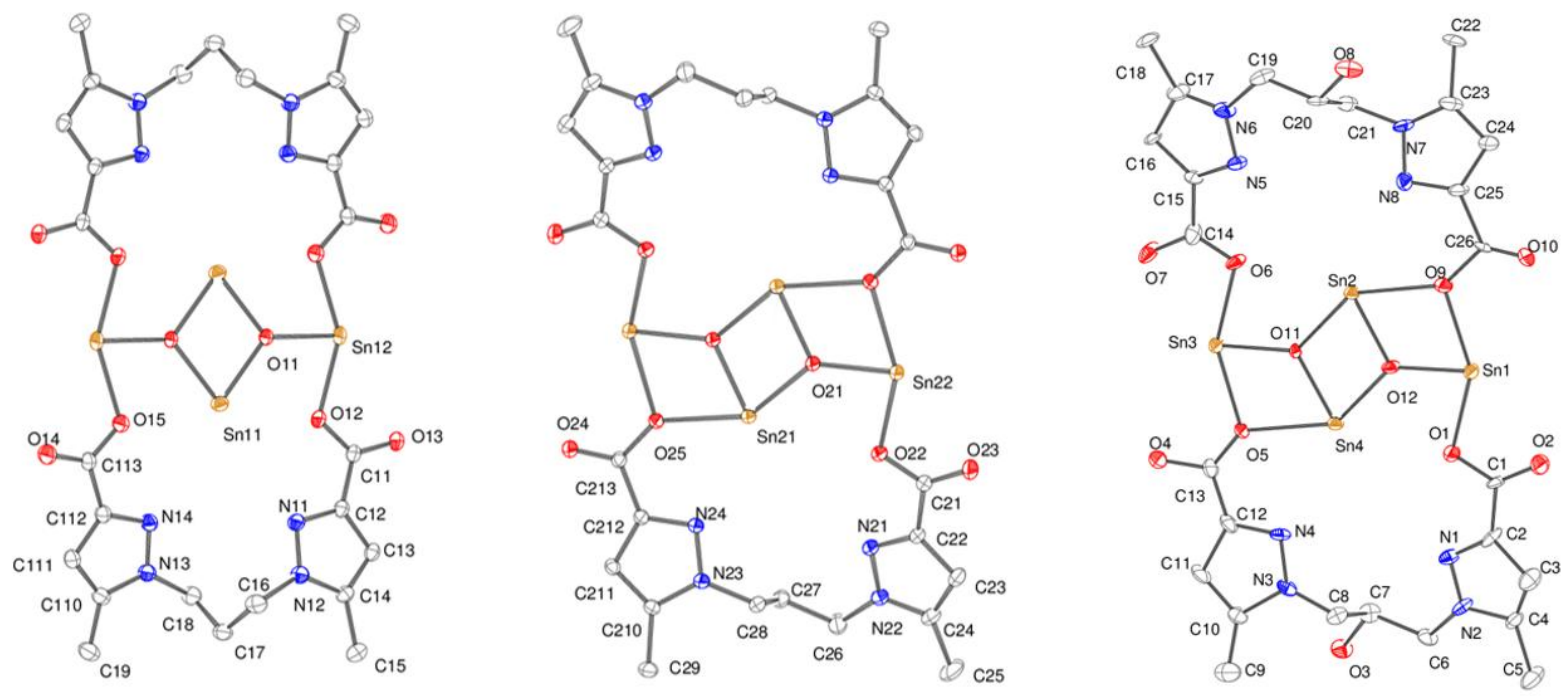

Fig. 7. The centrosymmetric $\mathbf{C 1}$ molecules (left and middle) and the non-centrosymmetric $\mathbf{C 2}$ molecule (right). (Atoms are labeled and butyl chains attached to Sn are omitted for clarity).

According to the Pearson database, the experimental Sn-O bonds are reported in the typical range of 1.90-2.25 ̊. This means that the Sn11 atom is bi-coordinated and the Sn12 atom is tri-coordinated in the first molecule of $\mathbf{C 1}$ (Fig. 8), while each of the Sn atoms of the second molecule (Sn21 and Sn22) is involved in two classical bonds and one long interaction of about $2.3 \AA$, out of range given for bond distances. The longer $\mathrm{Sn}-\mathrm{O}$ interatomic distances of $\sim 2.6$ and $\sim 3.3 \AA$ cannot be considered as bonds. The experimental geometry of the $\mathbf{C 2}$ molecule can be described with three classical $\mathrm{Sn}-\mathrm{O}$ bonds around $\mathrm{Sn} 1$ and $\mathrm{Sn} 3$ atoms and two classical bonds plus a long and most certainly non-bonding $\mathrm{Sn}-\mathrm{O}$ interaction of $\sim 2.4 \AA$ for the Sn2 and Sn4 atoms. It would be useful to compare these molecular geometries with that of an isolated molecule to assess the stresses to which molecules are subjected in the crystalline solid state. This is why we performed a geometry optimization for the $\mathbf{C 1}$ molecule in a DFT calculation (Dmol ${ }^{3}$, LDA/PWC functional, DND basis set). The distances within the $\mathrm{Sn}_{4} \mathrm{O}_{6}$ central core are given in Fig. 8 for the optimized molecule comparatively with the 
experimental distances measured for the molecules in the $\mathbf{C 1}$ and $\mathbf{C 2}$ crystal structures. In the optimized isolated molecule, $\mathrm{Sn} 1$ atom is involved in two $\mathrm{Sn}-\mathrm{O}$ bonds of 2.068 and $2.077 \AA$ and $\mathrm{Sn} 2$ atom in three $\mathrm{Sn}-\mathrm{O}$ bonds from 2.002 to $2.216 \AA$, all in the range of classical bonds, and the oxygen atoms distant by more than $2.6 \AA$ do not form bonds. Such a comparison provides information on how the molecule deforms in the crystal causing these oxygen atoms to move closer or further away from the Sn centers.
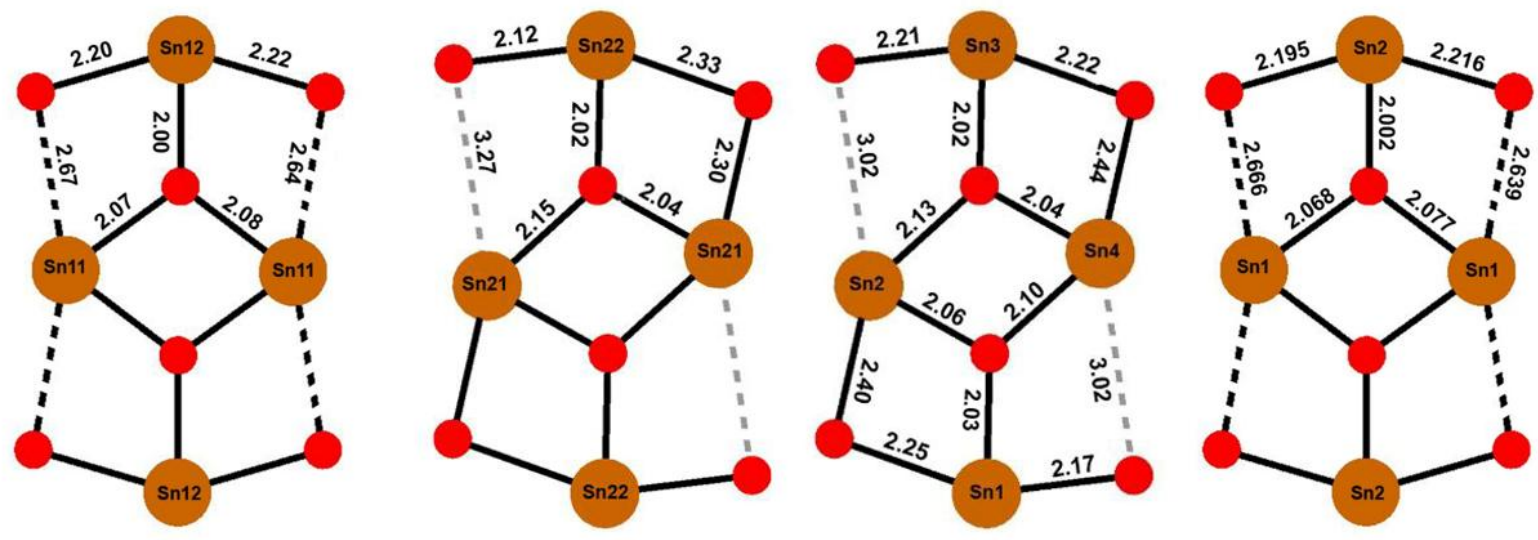

Fig. 8. The $\mathrm{Sn}-\mathrm{O}$ distances within the $\mathrm{Sn}_{4} \mathrm{O}_{6}$ central core in (left to right) the two molecules of $\mathbf{C 1}$, the molecule of $\mathbf{C 2}$, and the optimized isolated molecule of $\mathbf{C 1}$.

\subsection{Antifungal activity}

The organotin compounds C1-C2 and their corresponding ligands L1-L2 have been examined in vitro for their antifungal activity against Fusarium oxysporum f. sp. Albedinis (FOA) fungal. First, as can be seen in the results obtained collated in Table 2, the dose used affects the antifungal activity of the complexes and ligands.

Table 2. Antifungal activity of $\mathbf{C} 1$ and $\mathbf{C 2}$ complexes and corresponding $\mathbf{L} 1$ and $\mathbf{L} 2$ ligands. 


\begin{tabular}{|c|c|c|c|}
\hline Compound & $\begin{array}{c}\text { Volume } \\
\text { withdrawn }(\mu \mathrm{l})\end{array}$ & $\begin{array}{c}\text { Strain } \\
\text { diameter } \\
(\mathrm{cm})\end{array}$ & $\begin{array}{c}\text { Inhibition } \\
\%\end{array}$ \\
\hline \multirow{3}{*}{ C1 } & 40 & 8,5 & 0,00 \\
\hline & 160 & 8,5 & 0,00 \\
\hline & 500 & 0,8 & 90,59 \\
\hline \multirow{3}{*}{$\mathrm{C2}$} & 40 & 8,5 & 0,00 \\
\hline & 160 & 8,5 & 0,00 \\
\hline & 500 & 2,3 & 72,94 \\
\hline \multirow{3}{*}{ L1 } & 40 & 8,5 & 0,00 \\
\hline & 160 & 8,5 & $\mathbf{0 , 0 0}$ \\
\hline & 500 & 1,4 & 83,53 \\
\hline \multirow{3}{*}{ L2 } & 40 & 8,5 & $\mathbf{0 , 0 0}$ \\
\hline & 160 & 8,5 & $\mathbf{0 , 0 0}$ \\
\hline & 500 & 6,5 & 23,53 \\
\hline \multirow{3}{*}{ Benomyl } & 40 & 2,3 & 54,00 \\
\hline & 160 & 1,1 & $\mathbf{7 8 , 0 0}$ \\
\hline & 500 & 0,3 & 94,00 \\
\hline
\end{tabular}

The bipyrazole dicarboxylic acid ligands L1-L2 possess no activity towards FOA for volume withdrawal of 40 and $160 \mu$ l. An increase in volume up to $500 \mu$ l confers $\mathbf{L 1}$ some antifungal potency, while it remains rather weak for L2. The present finding proves the effect of the nature of the spacer between the two pyrazolic rings on the antifungal activity as is reported in one of our recent studies. ${ }^{13}$ For the complexes $\mathbf{C 1}$ and $\mathbf{C 2}$, it is clear that the coordination of di-n-butyltin by ligands $\mathbf{L} \mathbf{1}$ and $\mathbf{L} \mathbf{2}$ does not affect the antifungal activity at the volume withdrawal of 40 and $160 \mu \mathrm{l}$ which remains zero. By contrast, both complexes have shown activity at $500 \mu \mathrm{l}$ with values that are different. This indicates that the nature of the spacer between the two pyrazolic rings still affects the antifungal activity, as well as the presence of di-n-butyltin. The literature reports that the antifungal activity of tin complexes increases with the increase of their lipid-solubility. ${ }^{38,39}$ This give them the possibility to penetrate through the cytoplasmic membrane and then to become a possible site of action. ${ }^{40,41}$ Thus, the low activity of $\mathbf{C 2}$ can be explained by a lower lipid-solubility compared to that of C1. This is due to the presence of a hydroxyl moiety on the spacer between the two pyrazole 
cycles. Finally, despite their significant antifungal activities, these complexes remain with lower efficiencies than the positive control, the Benomyl.

\section{Conclusion}

In this paper, we have presented the synthesis of two new macrocyclic organotin (IV) carboxylates $\mathbf{C 1}$ and $\mathbf{C 2}$ based on bipyrazole dicarboxylic acid, which differ by the nature of spacers between the two pyrazole rings. This difference affects considerably their conformation as revealed by their single crystal X-ray structures. The NMR and FTIR spectroscopies as well as the elemental analyses are perfectly consistent with the structural determinations. The antifungal activity was investigated for the complexes $\mathbf{C 1}$ and $\mathbf{C 2}$ and the corresponding ligands $\mathbf{L} 1$ and $\mathbf{L} 2$ against Fusariumoxysporum f. sp. albedinis (FOA) and it depends on the presence of tin, on the nature of the spacer between the two pyrazole rings and on the dose used.

\section{Conflicts of interest}

No conflict of interest was reported by the authors.

\section{Appendix A. Supplementary data}

$\mathrm{CIF}$ files <CCDC 2070454> for $\mathrm{C}_{58} \mathrm{H}_{100} \mathrm{~N}_{8} \mathrm{O}_{10} \mathrm{Sn}_{4}$ (C1) and <CCDC 2070462> for $\mathrm{C}_{58} \mathrm{H}_{100} \mathrm{~N}_{8} \mathrm{O}_{12} \mathrm{Sn}_{4}, 4 \mathrm{H}_{2} \mathrm{O}(\mathrm{C} 2)$ are deposited at Cambridge Crystallographic Data Center.

\section{References}

1. A. J. Crowe, P. J. Smith and G. Atassi, Chem. Biol. Interact., 1980, 32(1-2), 171-178.

2. D. de Vos, R. Willem, M. Gielen, K. E. van Wingerden and K. Nooter, Metal-Based Drugs, 1998, 5, 179-188.

3. M. Nath, S. Pokharia, G. Eng, X. Song and A. Kumar, J. Organomet. Chem., 2003, 669, $109-123$. 
4. M. Nath, S. Pokharia, X. Song, G. Eng, M. Gielen, M. Kemmer and D. de Vos, Appl. Organomet. Chem., 2003, 17, 305-314.

5. A. G. Hadi, K. Jawad, D. S. Ahmed and E. Yousif, Syst. Rev. Pharm., 2019, 10(1), 26-31.

6. H. Iqbal, S. Ali and S. Shahzadi, Cogent Chem., 2015, 1(1), 1029039.

7. E. R. Tiekink, Appl. Organomet. Chem., 1991, 5(1), 1-23.

8. M. Gielen, Coord. Chem. Rev., 1996, 151, 41-51.

9. M. S. Ahmad, M. Hussain, M. Hanif, S. Ali and B. Mirza, Molecules, 2007, 12(10), 23482363.

10. C. E. Carraher Jr and M. R. Roner, J. Organomet. Chem., 2014, 751, 67-82.

11. C. E. Carraher, T. S. Sabir, M. R. Roner, K. Shahi, R. E. Bleicher, J. L. Roehr and K. D. Bassett, J. Inorg. Organomet. Polym. Mater., 2006, 16(3), 249-257.

12. A. F. Butt, M. N. Ahmed, M. H. Bhatti, M. A. Choudhary, K. Ayub, M. N. Tahir and T. Mahmood, J. Mol. Struct., 2019, 1191, 291-300.

13. M. Dahmani, A. Et-Touhami, A. Yahyi, T. Harit, D. Eddike, M. Tillard and R. Benabbes, J. Mol. Struct., 2021, 1225, 129-137.

14. L. Hu, H. Wang, T. Xia, B. Fang, Y. Shen, Q. Zhang, X. Tian, H. Zhou, J. Wu and Y. Tian, Inorg. Chem., 2018, 57(11), 6340-6348.

15. T. Sedaghat, M. Yousefi, G. Bruno, H. A. Rudbari, H. Motamedi and V. Nobakht, Polyhedron, 2014, 79, 88-96.

16. M. Nath, R. Yadav, M. Gielen, H. Dalil, D. de Vos and G. Eng, Appl. Organomet. Chem., 1997, 11(9), 727-736.

17. D. Kovala-Demertzi, V. Dokorou, A. Primikiri, R. Vargas, C. Silvestru, U. Russo and M. A. Demertzis, J. Inorg. Biochem., 2009, 103(5), 738-744.

18. M. Nath, M. Vats and P. Roy, Inorg. Chim. Acta., 2014, 423, 70-82. 
19. A. Corona-Bustamante, J. M. Viveros-Paredes, A. Flores-Parra, A. L. Peraza-Campos, F.

J. Martínez-Martínez, M. T. Sumaya-Martínez and Á. Ramos-Organillo, Molecules, 2010, 15(8), 5445-5459.

20. I. Ahmad, A. Waseem, M. Tariq, C. MacBeth, J. Bacsa, D. Venkataraman and S. Tabassum, Inorg. Chim. Acta., 2020, 505, 119433.

21. V. Chandrasekhar and R. Thirumoorthi, Organometallics, 2009, 28(7), 2096-2106.

22. V. Chandrasekhar, C. Mohapatra and R. J. Butcher, Cryst. Growth Des., 2012, 12(6), 3285-3295.

23. D. Du, Z. Jiang, C. Liu, A. M. Sakho, D. Zhu and L. Xu, J. Organomet. Chem., 2011, 696(13), 2549-2558.

24. A. S. Sougoule, Z. Mei, X. Xiao, C. A. Balde, S. Samoura, A. Dolo and D. Zhu, J. Organomet. Chem., 2014, 758, 19-24.

25. F. F. Yan, C. L. Ma, Q. L. Li, S. L. Zhang, J. Ru, S. Cheng and R. F. Zhang, New J. Chem., 2018, 42(14), 11601-11609.

26. I. Rojas-León, H. Alnasr, K. Jurkschat, M. G. Vasquez-Ríos, G. Gómez-Jaimes, H. Höpfl and R. Santillan, Organometallics, 2019, 38(12), 2443-2460.

27. S. Radi, A. Yahyi, A. Ettouhami, A. C. Jha, N. N. Adarsh, K. Robeyns and Y. Garcia, Polyhedron, 2015, 85, 383-388.

28. S. Radi, M. El-Massaoudi, H. Benaissa, N. N. Adarsh, M. Ferbinteanu, E. Devlin and Y. Garcia, New J. Chem., 2017, 41(16), 8232-8241.

29. T. Harit, H. Abouloifa, M. Tillard, D. Eddike, A. Asehraou and F. Malek, J. Mol. Struct., 2018, 1163, 300-307.

30. Bruker, APEX3. Version 2017.3-0, Bruker AXS, Inc., Madison, Wisconsin, USA, 2017.

31. G. M. Sheldrick, Acta Crystallogr., 2015, A71, .3-8.

32. G. M. Sheldrick, Acta Crystallogr., 2015, C71, 3-8. 
33. http://www.ccdc.cam.ac.uk/conts/retrieving.html (or from the CCDC, 12 Union Road, Cambridge CB2 1EZ, UK; Fax: +44 1223 336033; E-mail: deposit@ ccdc.cam.ac.uk)

34. R. Herbst-Irmer and G. M. Sheldrick, Acta Crystallographica Section B: Structural Science, 1998, 54(4), 443-449.

35. X. Du, R. Zhang, Q. Li, S. Cheng, Y. Li, J. Ru and C. Ma, J. Organomet. Chem., 2020, 121654.

36. T. Harit, M. Dahmani, S. Gaamouche, F. Malek, M. Dusek, A. Manseri and A. Asehraou, J. Mol. Struc., 2019, 1176, 110-116.

37. L.J. Farrugia, ORTEP-3 for Windows, an update, J. Appl. Crystallogr., 2012, 45, 849854.

38. D. C. Menezes, F. T. Vieira, G. M. De Lima, J. L. Wardell, M. E. Cortés, M. P. Ferreira and A. Vilas Boas, Appl. Organomet. Chem., 2008, 22(4), 221-226.

39. E. N. Iornumbe, S. G. Yiase, J. Audu and B. O. Ozide, Journal of Chemical Society of Nigeria, 2018, 43(4).

40. J. S. White and J. M. Tobin, Environ. Sci. Technol., 2004, 38, 3877-3884.

41. J. S. White and J. M. Tobin, J. Appl. Microbiol. Biotechnol., 2004, 63, 445-451. 